\title{
O USO INTERESSADO DO HUMOR POLÍTICO NAS CHARGES DA IMPRENSA DE FORTALEZA
}

Matilde de Lima Brilhante ${ }^{1}$

RESUMO

É objetivo deste texto desvelar os interesses no uso do humor gráfico (charge) para a construção dos fatos políticos divulgados na imprensa fortalezense. Percebendo que durante o mandato da prefeita Maria Luiza Fontenele (1986-1988) as charges dos dois principais jornais locais mantiveram, de forma sistemática, uma postura crítica a esta administração, buscamos analisar os interesses que motivaram essa produção. Nesse sentido a produção humorística não é neutra, nem tem como função apenas divertir o leitor, é, antes de tudo, uma linguagem produtora de sentidos que está interessada na defesa de uma dada visão de mundo e dos acontecimentos.

Palavras-Chave: Humor político. Produção de sentid. Uso interessado.

\section{ABSTRACT}

It is the aim of this text reveal the interests in the use of graphic humor (charge) for the construction of political facts in the press Fortaleza. Realizing that during the tenure of Mayor Maria Luiza Fontenele (19861988) the charges of the two major local newspapers have maintained consistently be critical in this administration, we analyze the concerns that motivated this production. In this sense the humorous production is not neutral, nor does it function just to amuse the reader, is, above all, a producer of meanings that language is interested in defending a particular worldview and of events.

Keywords: Political Humor. Meaning production. Use interested.

\section{Introdução}

O chargista, ao elaborar a crítica política por meio da imprensa jornalística, participa desse mundo político. Entretanto, essa participação não se define por oposição ou contrariedade aos políticos, pois, não é descartada a possibilidade de uma atuação favorável à algum político,

\footnotetext{
${ }^{1}$ Graduada em Licenciatura Plena em História pela Faculdade de Educação, Ciências e Letras do Sertão Central (2007). Mestre em História e Culturas pela Universidade Estadual do Ceará (2011).
} 
partido ou grupo político. Cartunista do jornal Diário do Nordeste, Hermínio Macedo Castelo Branco (Mino), afirma que durante a eleição estadual de 1986 publicava charges na televisão contra Adauto Bezerra (um dos concorrentes ao cargo de governo e disputava diretamente com Tasso Jereissati, já que eram os dois com maior número intenções de votos) e empolgado com a nova fase política do Brasil, começou a fazer charges a favor do político que adotava esse discurso mudancista, Tasso Jereissati. Com isso, um jornalista do mesmo jornal, Neno Cavalcante, do lhe telefona para dizer que chargista não pode ser a favor. A partir de então, o cartunista modificou sua proposta de trabalho.

Esse exemplo nos indica que a charge não é necessariamente uma produção contra políticos e/ou partidos, e quando torna-se crítica com relação aos políticos, não o é de forma mecânica, mas porque há interesses e/ou idéias a defender.

Sendo assim, este tipo de produção está inserida em um sistema de defesa de interesses, idéias e visão sobre os acontecimentos que são construídos como noticias pelos grupos jornalísticos. Sua busca pela construção de laços de identificação para com o público se apresenta como possibilidade de persuasão. Desta forma, o que estamos chamando de uso interessado do humor é a utilização do humor gráfico (charge) de maneira programada e sistemática em defesa do posicionamento do jornal.

Geralmente se percebe o humor como uma linguagem que se coloca contra uma determinada idéia/acontecimento, entretanto, se ela está a criticar uma dada situação é porque está a favor de alguma outra, defende uma idéia que é muitas vezes acautelada devido a essa capacidade que a linguagem chárgica possui de colocar um véu sobre seus produtores, ocultandoos enquanto sujeitos interessados.

Nesse texto, procuramos desvelar como a charge produziu sentidos e significações pautando-se nos acontecimentos da cena política e quais interesses estavam envolvidos nessa produção. Lembrando que o contexto que se insere nossa pesquisa é o da transição de regime político brasileiro, e nosso interesse recai sobre um fato em específico: a administração de Maria Luiza Fontenele na prefeitura de Fortaleza nos anos de 1986 a 1988.

\section{Tessitura de uma transição para democracia.}

Para o processo histórico brasileiro, a década de 1980 representou o resultado das lutas de diversos setores da sociedade contra a permanência de um regime político autoritário (que iniciara em 1964) baseado em um presidencialismo exacerbado de caráter militar, muito embora, tenha se firmado com a colaboração e auxílio de setores da sociedade civil. 
Tendo a União concentrado grande poder de decisão, a participação política da população estabeleceu-se a margem da legalidade do regime, já que uma legislação de caráter repressivo apresentava restrições à liberdade de organização, expressão e manifestação política, além de desconsiderar a intervenção eleitoral pelo voto direto. Sendo que o direito a estas formas de participação política - ou a negação destas - passava a ser compreendido num sentido mais amplo, que não apenas restrito a uma participação tornada pública, mas, assumia uma significação de cidadania. Ou seja, as diversas possibilidades de expressão política significavam um tornar-se cidadão, como uma condição política, mas também, como uma valoração do indivíduo como possuidor de um agir no mundo. Portanto, a privação desse direito retirava, além da liberdade política, o sentimento de sujeito de ação cívica.

Para modificar esse quadro, entre a segunda metade da década de 1970 e a primeira metade da década seguinte, as lutas pelo retorno à democracia se intensificam iniciando a construção do que Maria Paula Nascimento Araújo chama de "cena política legal ou pública”. Nas análises da autora, esta cena surge como uma tentativa de tornar visível o movimento de oposição à forma de governo vigente, assim o processo de transição é marcado pela atuação de um movimento político de oposição, reunindo amplos setores da sociedade e com forte presença de partidos e organizações considerados de esquerda. É, também, marcada pela pluralidade de atores políticos na cena publica, como por exemplo, os estudantes universitários, intelectuais e artistas.

Nosso objeto de análise se constrói dentro desse contexto político e cultural da década de 1980, quando o Brasil passava de um regime ditatorial para uma pretendida República Democracia. Esse período foi marcada por uma crescente discussão e participação da sociedade na vida política. Alguns eventos foram sintomáticos dessa nova cena pública: a Campanha das Diretas Já em 1984, as eleições diretas para prefeitura das capitais em 1985 e para governo estadual em 1986, aprovação de uma nova Constituição Federal em 1988.

Os governos militares atrasaram a mudança de regime político até meados da década de 1980 quando, ainda por meio de eleição indireta, José Sarney torna-se presidente. Pois, Tancredo Neves (PMDB) que havia disputado e vencido as eleições no Colégio Eleitoral contra Paulo Salim Maluf em janeiro de 1985, e internado às vésperas de sua posse para realização de uma cirurgia, veio a falecer posteriormente. Não chegou a assumir a presidência, o que conduziu seu vice, José Sarney, ao cargo.

Esse contexto político estava imerso numa crise econômica que abalou o país nos anos de 1980. As diversas tentativas de conter a inflação através de Planos e/ou Pacotes econômicos pareciam não fazer nenhum efeito. Assim, as charges da época sobre a crise financeira, revelam a construção e a difusão de um sentimento de preocupação quanto ao futuro da política econômica. 
Nesse campo a situação é marcada por um clima de instabilidade que penetrava no imaginário humorístico simbolizado pela imagem de um dragão. Com isso, dá-se a perceber as expectativas lançadas através dessa produção.

Figura 1 - Diário do Nordeste.

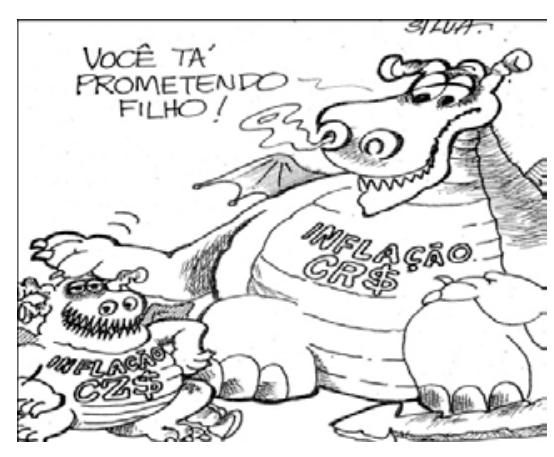

Fonte: Maurício Silva. 12.11.1986.

Fazendo uma leitura desta analogia (inflação-dragão), é possível visualizarmos, a dimensão tomada pela crise. Simbolicamente, o dragão significava o "mal", e este deveria ser detido para que as pessoas pudessem viver tranquilamente; um monstro causador da destruição. $\mathrm{Na}$ década de 1980, a inflação era esse mal que precisava ser combatido. $\mathrm{E}$ ainda, a charge na tentativa de imaginar o futuro, previa a permanência da situação ou até mesmo sua exacerbação. Do ponto de vista econômico, o momento causava preocupação no cidadão e ganhava cada vez mais espaço na imprensa jornalística relacionado a duas principais questões: a dívida externa e a inflação.

Em jornais cearenses da época como O Povo e Diário do Nordeste era destaque, quase que diariamente, notícias e opiniões a respeito da crise econômica, e em grande parte destas, a imagem do presidente, José Sarney, era suscitada como principal referencial na condução dos problemas econômicos.

Esse é o contexto que torna favorável um discurso de negação das formas políticas anteriores, fazendo surgir a idéia do novo como antítese de um modelo falho de tratar o político.

\section{Maria Luiza e a construção de um discurso da mudança.}

Atrelada a essa perspectiva mudancista, em 1985 ocorria a primeira eleição para as prefeituras das capitais após vinte anos de ditadura civil-militar. Concorriam para a 
administração municipal em Fortaleza: Antônio Paes de Andrade (PMDB); Lúcio Gonçalo de Alcântara (PFL); Maria Luiza Fontenelle (PT); Antônio Alves Moraes (PDS/PTB); Moema São Tiago (PDT); Humberto Beviláqua (PL) e Francisco Tarcísio Leite (PSC).

Nesta campanha inaugurava-se o discurso com a temática da mudança, tão explorado na disputa para governo estadual pela coligação Pró-Mudanças posteriormente (em 1986) no Estado do Ceará. Maria Luiza, candidata por um partido considerado de esquerda, defendia que Fortaleza era uma cidade oposicionista e quando entrevistada pelo jornal O Povo afirmou que "esta cidade sempre se caracterizou como eminentemente oposicionista. E hoje é muito mais que no passado". Embora se pense num confronto entre direita e esquerda, como o próprio Partido dos Trabalhadores (PT) deixou a mostra, o que prevaleceu foi antes uma oposição entre o velho e o novo, advindo da conjuntura política no plano nacional.

O tema da mudança parecia ser o grande mobilizador de opiniões, e naquela campanha foi utilizado ostensivamente por dois dos partidos concorrentes: PMDB e PT. O candidato do PMDB, Paes de Andrade, respalda-se em um discurso em defesa da democracia, exaltando a imagem de seu partido como opositor à ditadura civil-militar no Brasil. Para Maria Luiza, candidata do PT, os anseios de mudança do povo eram bem maiores que a concessões políticas feitas pela Nova República, uma vez que mantia o quadro econômico sem alterações, além de não fazer nenhuma opção prioritária pelo povo que continuava a conviver com inflação e desemprego.

Em relação à conjuntura histórica dos anos 80, o discurso de conteúdo mudancista utilizado na campanha de Maria Luiza (1985) diferenciava-se do discurso utilizado na campanha de Tasso Jereissati (1986) pela seguinte questão: Para a candidata à prefeita de Fortaleza, o país ainda precisava mudar, uma vez que as mudanças já conquistadas não eram suficiente diante dos anseios do povo. Para ela, deveria haver transformações mais profundas, de modo a resolver questões essênciais de cidadania. Enquanto o candidato à governo estadual, exaltava o cenário mudancista a nível nacional e o Estado do Ceará deveria seguir esse caminho, tendo as transformações nacionais como base desse projeto.

Além de exposição pública contra a ditadura, alimentava-se um discurso anti-coronelista entendido como perpetuação do regime ditatorial a nível local. Encontra-se nessa elaboração discursiva (da mesma forma que utilizada na campanha estadual de 1986 por Tasso Jereissati) a construção de uma imagem positiva conforme a negação de um outro fenômeno, nesse caso, o coronelismo. Esta forma de sobreposição estratégica não separa os discursos - "mudança" e "oposicionismo" - por completo, permanecem um dependendo sempre do outro. Assim, para a construção de uma imagem política positiva, na conjuntura que estamos analisando, era preciso negar o passado (lê-se práticas relacionadas a ditadura e por extensão o coronelismo a nível local); não a negação da existência deste passado, de sua relação com o que tornou-se "condenável" no mesmo. 
Tal assertiva nos leva a pensar que a concorrência no campo político é determinada pela elaboração de discursos de combate, em que não basta propôr uma imagem positiva de si, é preciso, também, anular o discurso do outro. Essa anulação se dá pela construção, muitas vezes simbólicas, de imagens negativas do outro, levando-o ao descrédito.

O resultado da eleição para prefeitura de Fortaleza, tendo Maria Luiza como vencedora, sugere que o discurso da mudança tendia a uma aceitação motivada pela resistência à ditadura como regime político dos anos anteriores. Por outro lado, não bastava um cenário propício, era necessário personagens políticos que construíssem identificações com as lutas do periódo, e ainda, levar essas identificações para as imagens exploradas durante a campanha. $O$ número total de votantes foi de 492. 802, distribuido da seguinte forma: Maria Luiza obtendo 159. 846 (32,43\%); Paes de Andrade 148. 437 (30,12\%); Alcântara 121.326 (24,61\%); Antônio Moraes 27. 204 (5,5\%); Tarcísio Leite 4.303 (0,8); Moema São Tiago 3.692 (0,7\%) e Humberto Beviláqua 405 votos.

\section{Os jornais e os chargistas.}

Nos periódicos O Povo e no Diário do Nordeste a charge, na década de 1980, era publicada no editorial, página em que se encontra a opinião do jornal e de leitores do jornal. Desta forma ela ocupava uma posição estratégica, cumprindo não só uma função informativa como também de entretenimento, sendo apresentada entre as primeiras páginas, o que demonstra a importância dada ao humor gráfico, visto que os espaços na imprensa jornalística obedecem a uma hierarquia quando a relevância do assunto, que é definida pelo editor.

O Povo contava com apenas um chargista para suas publicações do editorial, este era Sinfrônio de Sousa Lima Neto. Os outros desenhistas presentes no jornal trabalhavam no setor de ilustração, estas poderiam surgir em qualquer página, não sendo, obrigatoriamente, uma publicação diária. Já no Diário do Nordeste havia quatro chargistas, eram eles: Glauco Bezerra Martins, Maurício Silva, Hermínio Macedo Castelo Branco (conhecido como Mino) e Eris. Estes revezavam o espaço destinado a publicação diária ao lado do editorial.

A compreensão da prática do humor na imprensa implica a visualização dos sujeitos responsáveis por ela. Cada chargista possuía um estilo próprio, uma visão distinta sobre a linguagem do humor e, nem mesmo o fato de trabalharem no mesmo jornal, seguindo a mesma linha editorial promovia uma produção uniforme. Isso porque o processo de criação da charge tem em si a individualidade do profissional.

Os chargistas afirmam exercerem uma função relevante nesse espaço de atuação, qual seja o de dizer o que muitos gostariam de dizer e não têm como, Maurício Silva vai além, e diz 
serem "militantes das causas populares". Mas, o chargista que atua na imprensa jornalística tem seu trabalho enquadrado na proposta editorial do jornal, então, seriam as causas populares as mesmas defendidas pelos jornais? Não exatamente. A questão é que sendo preciso haver correspondência de interesse entre autor e público, o chargista defende as causas populares na medida em que estas não vão contra a posição do jornal, ou seja, até onde ele consegue articular e mediar esses interesses.

Podemos dizer que o chargista é um tipo de intelectual que pensa o cotidiano em suas relações mais conflitantes. Se o intelectual pensado por Norberto Bobbio é o criador ou transmissor de idéias ou conhecimentos politicamente relevantes, nossos chargistas se dirigem ao leitor do jornal tematizando indivíduos, idéias ou acontecimentos.

Bobbio estabelece uma tipologia dessa categoria sob a noção de ideólogos, aqueles que fornecem princípios-guia, e expertos, aqueles que fornecem conhecimentos-meios. Ora, a relação do chargista com a política, seus espaços e formas de atuação é distinta e não se enquadra na tipologia do filósofo. Pois, se os ideólogos elaboram os princípios com base nos quais uma ação é justificada, ou seja, a ação é legitimada e os expertos indicam os conhecimentos mais adequados ao alcance de um fim, os chargistas não agem pautando-se apenas na fidelidade a princípios, nem propõem meios adequados a fins. Portanto, não falam para o político, e sim, sobre o político.

Mas sendo o chargista um intelectual, em um ponto suas relações com a política parecem caminhar em direção ao que foi pensado por Norberto Bobbio: existem vários modos com que se podem representar as relações entre os intelectuais e o poder. Nesse sentido, o chargista tanto pode se propor a legitimar o poder quanto a criticá-lo. Encontra-se numa posição em que não é integrante do poder, mas também não está totalmente fora deste. Assim, esses profissionais do humor não correspondem a um todo homogêneo, cada um se percebe de maneira distinta.

\section{Charge e o humor político.}

Como comprender a linguagem humorística numa relação com o mundo político sem levar em consideração os usos que dela é feito?

Em 2010 vemos surgir um debate na imprensa brasileira sobre a liberdade e censura para a prática do humor. Num período em que nos aproximamos das eleições para presidente do país, governo dos Estados, deputados e senadores.

O debate surge em decorrência da Lei $\mathrm{n}^{\circ}$ 9. 504/97, que disciplina as campanhas eleitorais, na qual, em seu artigo 45 determina que a partir do $1^{\circ}$ de julho de cada ano eleitoral, as rádios e 
televisões ficam proibidas de veicular filmes, novelas, minisséries e programas com "trucagem, montagem ou outro recurso de áudio ou vídeo que, de qualquer forma, degradem ou ridicularizem candidato, partido ou coligação". O dispositivo também proíbe as rádios e televisões de veicularem programas com "alusão ou crítica" a políticos e candidatos "mesmo que dissimuladamente". As emissoras que infringirem essa proibição ficam sujeitas a multas de até R\$ 200 mil.

A Associação Brasileira de Emissoras de Rádio e Televisão (Abert), contando com o apoio de jornalista, intelectuais, humoristas, artistas de teatro e tevê e da ONG Repórteres sem Fronteiras (que se diz defender a liberdade de imprensa) entra com recurso questionando a constitucionalidade da Lei. O resultado foi uma liminar concedida pelo vice-presidente do Supremo Tribunal Federal, Ayres Brito, liberando os programas humorísticos para o uso do humor com candidatos às eleições.

Jornais como $O$ Estado de S. Paulo, O Globo, O Povo e Diário do Nordeste utilizaram suas páginas para destacar a importância da linguagem humorística para os debates numa sociedade, que se pretende, democrática. Quanto à lei 9.504, de 1997, que regulamenta as restrições aos humoristas durante o período eleitoral, os jornais, citados acima, se posicionaram contrários por considerá-la uma ameaça à liberdade de expressão e de imprensa.

O problema é que essa proibição é, sem dúvida, uma forma de censura, colidindo frontalmente com o artigo $5 .^{\circ}$ da Constituição, que consagra as liberdades de informação, de expressão e de opinião no rol das garantias fundamentais e das liberdades públicas. Por conciliar crítica com ironia, as imitações e sátiras, desde a antiguidade helênica, nada mais são do que expressões artísticas e criativas de manifestação do pensamento. (Editorial Folha de São Paulo; 32.08.2010)

Essa discussão coloca em evidência o conflito entre a produção humorística e seus limites de criação. Seria, de fato, relevante levantar as seguintes questões: Teria a linguagem humorística uma função política a exercer na sociedade atual? E quais os limites desse humor?

A nossa resposta é que, a atividade específica do humor é intervir na realidade através da exposição ridícula de personalidades públicas, lançando-se nas discussões, quase sempre políticas, defendendo idéias e atitudes por meio do fazer rir. Alcança um grande número de pessoas por se apresentar de forma divertida e de rápida assimilação, talvez ainda, pela idéia de superioridade despertada no ridente.

Os limites das expressões do humor parecem depender de algo muito geral e, ao mesmo tempo, de circunstâncias muito pontuais. $O$ dispositivo geral de controle - do que pode ou não ser 
tomado como tema nesse tipo de produção - corresponde aos interesses dos próprios produtores. Nesse sentido, as polêmicas geradas com as publicações de charges e caricaturas apontam para isso, uma vez que atestam o não compromisso com o pensamento daqueles que o humor toma como objeto. Portanto, os profissionais dessa linguagem levam em consideração a não ofensa aos interesses interno, que seja dele próprio ou de um grupo para o qual trabalha; fora esse espaço interno de interesses, o humor parece não dispor de preceitos antecipadamente determinados para definir o que pode ou não ser tomado como conteúdo de tal produção.

Com isso, quem torna-se alvo do humor é um outro, aquele que encontra-se fora do grupo, e, este não dispõe de mecanismos de controle prévio. Entendemos que no caso da Lei 9.504/97 que procura preservar o outro, ou seja, os sujeitos passíveis de serem tomados como ridículos na linguagem humorística - mais que uma tentativa de controle é uma interdição no espaço de atuação do humor movida pelo temor à sua capacidade de rebaixar e humilhar seus personagens.

Contudo, a decisão favorável a liberação do humor no período antecedente às eleições, bem como os discursos dos ministros que votaram a favor da medida, ou até mesmo o fato de se levar a discussão para a ordem jurídica, demonstra que o humor ocupa um espaço de destaque na imprensa brasileira, inserido nos debates de questões públicas. É perceptível que a linguagem humorística detém grande poder de comunicação, e, é utilizada por uma quantidade considerável de programas de TV e rádio, além de jornais e revistas.

Nesses termos, acreditamos que há um riso provocador, acusador e que, por sua vez, atua politicamente independente de sua tomada de posição. $O$ humor que vamos discutir nesse texto não é o humor simplesmente cool e fun, mas o que produz um sentido para além da diversão.

Sendo o riso uma manifestação inerente ao ser humano, vivenciado por meio de práticas culturais, é pertinente que esse fenômeno seja pensado em termos históricos. Ele não é uma expressão aleatória. Apesar de ser um prazer natural, não existe sem uma causa; é necessária uma prática, uma razão capaz de chamá-lo a vida. Ninguém ri porque decidiu manifestar o riso, mas porque se sentiu compelido a externar uma sensação que foi produzida mediante uma situação humorística. A charge, portanto, constitui um meio, e não um fim na produção de sentidos e significações dos acontecimentos diários.

Sendo assim, o que estamos chamando de humor político pode ser entendido como o humor, na vertente charge, que participa no mundo político imprimindo e/ou exprimindo uma determinada visão dos acontecimentos da cena política de acordo com interesses defendidos pelo jornal. A crítica que ela exerce faz parte do projeto editorial da empresa jornalística da qual não pode ser estudada desvinculada.

Por isso, esta é uma produção que sempre está a favor ou contra uma ideia; nunca é neutra e sempre tem algo a nos revelar por trás do aparentemente engraçado e divertido. 


\section{A charge e a produção de sentidos sobre a Administração Popular de Fortaleza.}

Ao assumir a Prefeitura Municipal de Fortaleza em 01 de janeiro de 1986, Maria Luiza Fontenele torna-se referencia constante na produção do humor gráfico dos principais jornais $\mathrm{O}$ Povo e o Diário do Nordeste. Inicia-se a construção da imagem de Maria Luiza na linguagem do humor. Humor este, que tem interesses a defender; que se posiciona diante dos acontecimentos.

As charges oferecem uma leitura sobre essa administração a partir da idéia de fracasso da prefeita em exercício, desta forma, marcavam a personagem (Maria Luiza) não como prefeita, mas como uma pedinte de esmolas. No primeiro mês de seu mandato sobressaia a falta de êxito de Maria Luiza em suas tentativas de conseguir financiamento junto ao presidente José Sarney para viabilizar as medidas de governo. As imagens em que Maria Luiza aparece como mendiga sugerem a inabilidade da personagem como administradora, à esta imprimindo a percepção do descrédito.

Como é possível observar na charge a seguir, a prefeita é caracterizada pela ausência de poder, indicando o estado de penúria da administração, já que a imagem de Maria Luiza é a imagem de sua administração.

Figura 02. Glauco

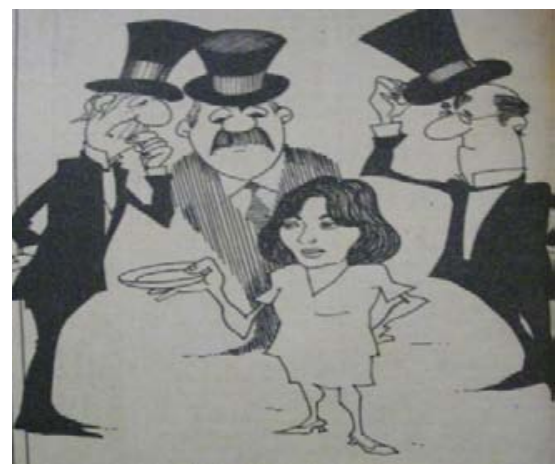

Fonte: Diário do Nordeste. 09.01.1986.

Nessa imagem, o desenhista explora a imagem da prefeita como pedinte na tentativa de expô-la ao riso público, pois ela aparece em situação humilhante. Vejamos, por exemplo, a 
indiferença com que os outros personagens da cena (um deles é o então presidente José Sarney) olham Maria Luiza. Essa cena figura a destituição da prefeita do poder.

Em uma outra situação, o chargista do O Povo, Sinfrônio, toma essa mesma perspectiva para a criação de uma charge. $O$ fato em específico é a chegada de José Sarney ao Ceará para a inauguração do Memorial de Padre Cícero, em Juazeiro do Norte. Na ocasião Maria Luiza declarou que entraria em Greve de fome, numa manifestação contra o tratamento que Fortaleza recebia por parte do governo, basicamente, se referia à falta de recursos financeiros para a recuperação de ruas e avenidas destruídas pelas chuvas do início do ano e para o pagamento do funcionalismo público municipal.

Embora se reportando a um acontecimento em específico, o desenhista pretende levar o leitor a pensar em um panorama mais amplo, ou seja, entende que recorrer aos ministérios e/ou órgãos públicos, bem com ao próprio presidente, para aquisição de recursos financeiros é uma atitude de rebaixamento, e como tal torna-se merecedora de derrisão.

Figura 03 - Sinfrônio

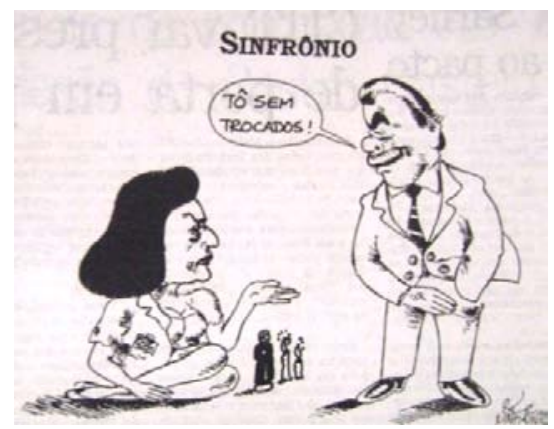

Fonte: O Povo. 27. 07.1988.

Apesar de assinalar a não contribuição de Sarney para com a prefeita, o centro de interesse do chargista não é a falha do presidente, e sim, a situação em que se encontra a prefeita. A imagem põe à disposição a idéia de que a prefeitura encontra-se em estado de miséria e, ao invés de Maria Luiza encontrar uma solução como administradora, procura resolver a questão pedindo esmolas ao governo federal, traduzindo-se numa atitude de rebaixamento moral.

Nos dois jornais essa imagem se repete. Encontramos quatro charges elaboradas nessa mesma perspectiva, e tanto no O Povo quanto no Diário, a mensagem parece ser: uma administradora negociaria com o presidente, e não, pediria esmolas. Assim, se pretendia obter o aspecto humorístico através da suposta incapacidade administrativa da prefeita, apresentando-a de forma humilhante. Há ainda, na charge, indícios de uma desforra de Sarney, pelo fato de Maria Luiza manter uma postura de oposição ao presidente e não revelar apoio ao Plano Cruzado, o que teria inviabilizado o apoio do governo federal à administração municipal. Desta forma, o 
chargista apresenta Sarney com uma expressão facial indicando contentamento com sua condição de superioridade, uma vez que a frase "tô sem trocados" trata-se, nesse caso, de uma sentença que reafirma a condição humilhante da personagem que pede esmolas.

As charges mostram que a administração de Maria Luiza esteve distante não só do governo federal como também do governo estadual. Nesse caso, as dificuldades passavam também pela questão da liberação de recursos. Nos dois casos a exposição de forma decadente da prefeita demonstra uma intencionalidade em promover o descrédito da administração. Pois, como acreditar numa prefeita que anda de pires na mão pedindo trocados?

No Diário do Nordeste era comum a publicação de charges apontando vereadores como uma classe que agia em benefício próprio, uma imagem recorrente é a de pessoas correndo com medo de vereador, dando a entender que não eram merecedores de confiança. Outras representações sobre a Câmara Municipal de Fortaleza, nas charges do O Povo, faziam a associação dos vereadores com a ociosidade. Em contra partida, os vereadores afirmavam haver na imprensa local uma disposição para desmoralização e desqualificação do trabalho realizado pelo poder legislativo. A charge a seguir é uma indicação do embate entre a prefeita e a Câmara municipal. Expõe o legislativo como força opositora à Maria Luiza, mas por se tratar de uma linguagem que tem no humor o elemento central da construção de sentido, o "alvo" da crítica é, principalmente, a prefeita.

Figura 4 - Sinfrônio.

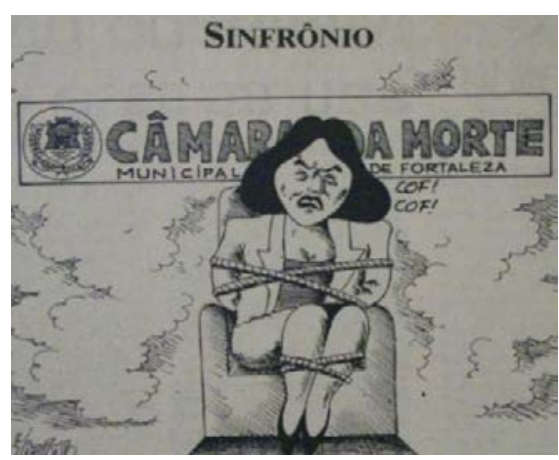

Fonte: O Povo. 16. 05.1987.

Sinfrônio apresenta a prefeita amarrada diante da Câmara Municipal, e reporta-se a idéia de câmara da morte - numa referencia à câmara de gás, como sugere as nuvens de fumaça atrás da personagem - para evidenciar a posição de Maria Luiza diante do quadro político vigente. Numa alusão à falta de poder da prefeita, a charge oferece uma leitura sob a configuração da Câmara Municipal de Fortaleza como algo extremamente nocivo à existência da personagem, mas, é claro, que existência como administradora municipal. Nesse sentido, é um prognóstico, 
embora não se cumprindo, sobre o fim da administração de Maria Luiza antes do término de seu mandato, tendo em vista o obstáculo que o legislativo representava naquele momento para o executivo municipal.

A charge é publicada num momento em que Maria Luiza denuncia irregularidade na Câmara de vereadores e acusa o Legislativo Municipal de tentar desestabilizar seu mandato. Para ela, isso se dá a partir do instante em que vereadores realizam trabalho nos bairros no sentido de convencer a população sobre sua renuncia. Mas apesar da cassação do mandato da prefeita ter sido cogitada pela Câmara não chegou a ser votada pelo legislativo. Na discussão que se travou na Câmara sobre essa questão, o vereador do PC do B, Francisco Lopes, manteve uma posição de repudio a todas as tentativas de cassação da prefeita, a bancada pedetista, composta por Araújo de Castro, Samuel Braga e Paulo Facó, também se posicionaram contra o pedido de cassação do mandato de Maria Luiza

A charge expõe a relação conflituosa entre a prefeita e o legislativo municipal, assim, quando o chargista opta pela exposição da imagem de Maria Luiza sendo sufocada pela fumaça da Câmara Municipal, expressa a idéia formulada ao captar o clima que se construiu entre os dois setores do poder municipal e, percebendo a imobilidade da prefeita, aponta um dos fatores que contribuía para tal imobilidade: as ações da Câmara Municipal. Por outro lado, a charge não é uma tentativa de vitimizar a prefeita, há sim, a exposição de sua incômoda situação, com o legislativo revogando decretos do executivo municipal ou pedindo intervenção do governador, Gonzaga Mota, na prefeitura. Mas a charge também comporta-se como uma representação a respeito da incapacidade da prefeita em desprender-se dos fatores restritivos da administração.

As charges dedicadas ao tema das dificuldades da gestão de Maria Luiza mostram esses condicionantes das ações da prefeita, mas a criação de sentido, como linguagem humorística, se dá através da exposição das fraquezas e da suposta incapacidade gerencial da administração municipal em fazer funcionar a máquina administrativa. Simbolizando a imagem do descaso publico criada para a prefeita, muitas charges foram publicadas apresentando a cidade tomada pelo lixo e com as ruas esburacadas.

Figura 05 - Glauco.

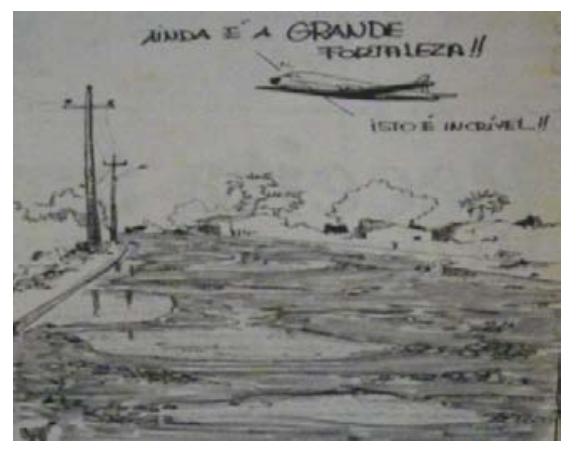

Fonte: Diário do Nordeste. 25. 05.1988. 
Na figura 05, expressando uma representação do último ano do governo de Maria Luiza, a cidade encontra-se abandonada, toda esburacada e inundada; sendo que no alto da figura há a frase: Ainda é a grande Fortaleza! Isso é incrível. O chargista deixa claro que o não cuidado com a cidade é algo que ocorre desde o início da administração, ao utilizar a palavra ainda, pretende afirmar que não houve mudanças nas condições das ruas da cidade, e, portanto, permanecia um caos.

A conclusão da frase é irônica, uma vez que a afirmação de que a situação da cidade (no desenho) é incrível se diz o contrário daquilo que se quer dá a entender. Essa afirmação irônica cria o efeito humorístico da charge, ao mesmo tempo em que formula a crítica contra a administração municipal. A crítica que se configura recai sobre a permanência das ruas esburacadas, sendo que, o chargista destaca os mais de dois anos que a administração teve para solucionar tal problema e assim não o fez.

\section{Considerações finais.}

Tal produção engendrou uma disputa pelo poder na concorrência sobre a forma de (re) apresentar os fatos políticos da cidade. O Povo e o Diário do Nordeste, detentores de uma orientação política contrária à proposta do grupo governista de Maria Luiza, promoviam a divulgação, por intermédio do humor gráfico, de representações que desqualificavam a administração municipal, e assim, essas empresas jornalísticas se fortaleciam no jogo político, uma vez que a disputa no campo das imagens públicas implica uma disputa pela produção da crença e da legitimidade do dizer.

Embora a prefeita, Maria Luiza, tenha procurado combater essa visão negativa de seu governo, procurando expor nesses mesmos jornais notícias sobre as obras realizadas pela prefeitura, o que prevaleceu na e pela imprensa foi a imagem de um governo fracassado.

O humor sendo utilizado para fins políticos na imprensa de Fortaleza nos mostra a possibilidade de construções dos acontecimentos através de instrumentos como a mídia imprensa. E ainda, como uma linguagem de grande poder de persuasão funciona dentro desse jogo de poderes. Portanto, embora o chargista seja o profissional encarregado pela criação, ele está ligado ao jornal pela relação patrão-empregado, e que portanto, seguirá a linha editorial do jornal. 


\section{Referências}

\section{Fontes:}

O Povo;

Diário do Nordeste;

Folha de São Paulo

Acervo: Setor de Periódicos da Biblioteca Pública Governador Menezes Pimentel.

\section{Bibliografia}

ALBERTI, Verena. $O$ riso e o risível na história do pensamento. $2^{\mathrm{a}}$ ed. Rio de Janeiro: Jorge Zahar Ed, 2002.

ACSELRAD, Márcio. Quem ri por último ri melhor? Uma análise do humor na hipermodernidade a partir do programa Custe o que Custar. In: Revista FAMECOS. Porto Alegre. v. 17. n. 1. p. 54-64. Janeiro/abril, 2010.

BAKTHIN, Mikhail. A cultura popular na Idade Média e no Renascimento: o contexto de François Rabelais. São Paulo: HUCITEC; Brasília: Editora da Universidade de Brasília, 1993.

BAUDELAIRE, Charles. Escritos sobre arte. São Paulo: Hedra, 2008.

BERGSON, Henri. $O$ riso: ensaio sobre a significação da comicidade. São Paulo: Martins Fontes, 2001. (coleção tópicos)

BOBBIO, Norberto. Os intelectuais e o poder: dúvidas e opções dos homens de cultura na sociedade contemporânea. São Paulo: Editora da Universidade Estadual Paulista, 1997.

FONSECA, Joaquim da. Caricatura: a imagem gráfica do humor. Porto Alegre: Artes e ofícios, 1999.

LIPOVETSKY, Gilles. A era do vazio: ensaio sobre o individualismo contemporâneo. Barueri, SP: Manole, 2005.

LUSTOSA, Isabel. Brasil pelo método Confuso: humor e boemia em Mendes Fradique. Rio de Janeiro: ed. Bertrand Brasil, 1993.

MINOIS, Georges. História do riso e do escárnio. São Paulo: UNESP, 2003.

MOTTA, Rodrigo Patto Sá. Jango e o golpe de 1964 na caricatura. Rio de Janeiro: Jorge Zahar Ed., 2006. 
BARBOSA, Marialva. História cultural da imprensa: Brasil, 1900-2000. Rio de Janeiro: Mauad X, 2007.

BENJAMIN, Walter. Magia e técnica, arte e política: ensaios sobre literatura e história da cultura. 7. ed. São Paulo: Brasiliense, 1994. (Obras escolhida; v. 1)

BOURDIEU, Pierre. O poder simbólico. Rio de Janeiro: Bertrand Brasil, 11ª ed.,2007.

. A produção da crença: contribuição para uma economia dos bens simbólicos. Porto Alegre: Zouk, $3^{\mathrm{a}}$ ed., 2006.

CAPELATO, Maria Helena Rolim. A imprensa na história do Brasil. São Paulo: Contexto/EDUSP, $2^{\mathrm{a}}$ edição, 1994.

CHARTIER, Roger. A história cultural: entre práticas e representações. $2^{\text {a }}$ edição. Difel, 2002.

. À beira da falésia: a história entre certezas e inquietudes. Porto Alegre: Ed. Universidade/UFRGS, 2002.

. A história hoje: dúvidas, desafios, propostas. In: Revista de Estudos Históricos. Rio de Janeiro, vol. 7, n. 13, 1994.

GINZBURG, Carlo. Mitos, emblemas, sinais: morfologia e hiatória. São Paulo: Companhia das Letras, 1989.

JOLY, Martine. Introdução à análise da imagem. Campinas, SP: Papirus,1996 (Coleção Ofício de Arte e Forma).

ROLLEMBERG, Denise. "Memória, Opinião e Cultura Política. A Ordem dos Advogados do Brasil sob a Ditadura (1964-1974)". Daniel Aarão Reis; Denis Rolland. (Orgs.). Modernidades Alternativas. Rio de Janeiro: Ed. Fundação Getúlio Vargas, 2008, p. 57-96.

SADER, Eder. Quando novos personagens entram em cena: experiências, falas e lutas dos trabalhadores da Grande São paulo. Rio de Janeiro: Paz e Terra, 1988.

Recebido em 30/02/2012

Aprovado em 30/05/2012 